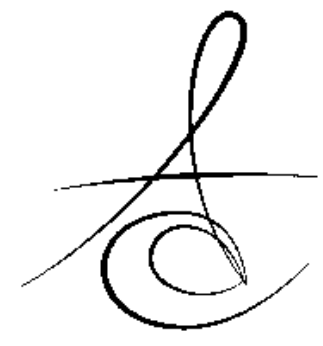

\title{
AN ASSESSMENT OF SUCCESS OF DENTAL IMPLANTS PLACED WITH IMMEDIATE AND STANDARD METHODS IN PERIODONTALLY COMPROMISED PATIENTS
}

\section{PERIODONTAL OLARAK PROBLEMLI HASTALARDA İMMEDİYAT VE STANDART YÖNTEMLERLE YERLEŞTİRİLEN DENTAL İMPLANTLARIN BASARISININ DEĞERLENDİRİLMESİ}

\author{
Dr. Öğr. Üyesi Adnan KILINç* \\ Dr. Öğr. Üyesi Tuğba AYDIN*** \\ Prof. Dr. Ümit ERTAS
}

\author{
Dr. Öğr. Üyesi Mustafa GÜNDOĞDU** \\ Arş Gör. Mehmet Zahit BAŞ* \\ Prof. Dr. Ertunç DAYI*
}

Makale Kodu/Article code: 3332

Makale Gönderilme tarihi: 25.01.2017

Kabul Tarihi: 07.06.2017

\section{ABSTRACT}

Aim: The aim of this study was to evaluate the success rates of implants placed in alveolar sockets immediately after the extraction of teeth or with a standard approach in normal alveolar bone in periodontally compromised patients.

Material and Methods: In this study, patients who had implant placement both into healed bone after previous extraction and into the alveolar sockets in the same surgical session after extraction of periodontally hopeless teeth that had inadequate attachment and bone loss who could not be treated were selected for inclusion. Implant success, complications, and failures were recorded during follow-up.

Results: Twelve patients (four female and eight male) ranging in age from 27 to 62 years (mean 48.6 years) were studied; the mean duration of follow-up was 27 months (range 18-36 months).. A total of 152 implants were placed ( 89 in the maxilla, 63 in the mandible). Of these, $83(54.6 \%)$ were placed immediately into alveolar sockets following extraction and $69(45.4 \%)$ into normal alveolar bone. The success rate for all immediately placed implants was $97.6 \%$, and the success rate for all implants placed as non-immediate was $98.6 \%$.

Conclusion: The study findings show that both immediate implant placement and non-immediate implant placement in periodontally compromised patients receiving treatment of implant-supported fixed full or partial prostheses are safe and preferable treatment modalities.

Keywords: Immediate dental implant, implant survival, periodontitis, immediate implantation, non-immediate implantation, implant survival, periodontally compromised sites

\section{öz}

Amaç: Bu çalışmanın amacı, periodontal problemli hastalarda diş çekiminin ardından alveoler soketlere immediyat olarak yerleştirilen ya da normal alveoler kemiğe standart yaklaşım ile yerleştirilen implantların başarı oranlarını değerlendirmektir.

Gereç ve Yöntem: Bu çalışmaya, hem daha önceden yapılmış diş çekimleri sonrası iyileşmiş kemiklere hem de uygun olmayan ataçman ve kemik kaybı sebebiyle tedavi edilemeyecek olan periodontal açıdan umutsuz dişlerin çekimi ile aynı cerrahi işlemde alveoler soketlere implant yerleştirilen hastalar dahil edilmiştir. Takip süresi boyunca implant başarısı, komplikasyonlar ve kayıplar kaydedilmiştir.

Bulgular: Yaşları 27 ile 62 arasında on iki hasta (4 bayan ve 8 erkek) çalışmaya alınmıştır; ortalama takip süresi 27 aydır (18-36 arası). Toplam 152 implant yerleştirilmiştir ( 89 adet maksillaya, 63 adet mandibulaya). Bunların 83 tanesi $(\% 54,6)$ diş çekimini takiben immediate olarak ve 69 tanesi $(\% 45,4)$ normal alveoler kemiğe yerleştirilmiştir. İmmediayat olarak yerleştirilen implantların başarı oranı $\% 97,6$ ve immediyat olarak yerleştirilmeyen implantların başarısı \%98,6 olarak gösterilmiştir.

Sonuç: Çalışma sonuçları göstermektedir ki; periodontal problemli hastalara hem immediayat hem de immediayat olmayan prosedürlerle yerleştirilen implantlar ile uygulanan implant destekli sabit tam ve bölümlü protezler güvenli ve tercih edilebilir bir tedavi seçeneğidir.

Anahtar Kelimeler: Acil dental implant, İmplant sağkalımı, İmmediayat implantasyon, implant sağkalımı, periodontal problemli bölge

* Department of Oral and Maxillofacial Surgery, Faculty of Dentistry, Ataturk University, Erzurum

** Department of Prosthodontics, Faculty of Dentistry, Ataturk University, Erzurum

*** Department of Periodontology, Faculty of Dentistry, Ataturk University, Erzurum 
Atatürk Üniv. Diş Hek. Fak. Derg.

J Dent Fac Atatürk Uni

Cilt:28, Sayı:2, Yıl: 2018, Sayfa, 216-221

\section{INTRODUCTION}

Today, implant therapy is a routine procedure used for restoring the completely or partially edentulous mouth. The standard protocol for implant placement requires a 6-month waiting period following tooth extraction. ${ }^{1}$ However, alveolar ridge resorption after tooth extraction may considerably reduce the residual bone volume and affect the favorable positioning of implants, which is required for optimal restoration. ${ }^{2,3}$ The idea has been proposed of placing the implant immediately into fresh extraction sockets in order to overcome such disadvantages. ${ }^{4,5}$ On the other hand, some studies suggest that the bone dimensions of immediate implant sites demonstrated a reduction in vertical and horizontal aspects following surgery. ${ }^{6}$ Immediate implant placement offers many advantages for both the patient and the clinician, including better bone and soft tissue preservation, shorter total treatment time, fewer surgical sessions, and greater patient acceptance. ${ }^{2-5}$

The fact that standard and immediate implant therapies are very successful and predictable has been well documented in numerous studies. ${ }^{7-10}$ However, contradictory information seems to be available concerning the prognosis of implants placed in periodontally compromised patients. Some investigators have suggested that periodontally compromised patients are at a higher risk of losing implants. ${ }^{11-13}$ However, other investigators did not find an important association between failed implants and a history of periodontal disease. ${ }^{14-16}$ On the other hand, some studies on immediate implants suggest that this procedure should be avoided in the presence of periodontal pathosis. ${ }^{17-19}$ In a study, implants placed in sites where teeth were extracted for periodontal reasons were 2.3 times more likely to fail than implants placed in other sites. ${ }^{20}$ But there are studies that give a good survival rate for immediate implantation. ${ }^{21,22}$ In light of this information, it is observed that there is a need for comparative studies on the survival rates of implantation with a standard approach or an immediate approach in periodontally compromised patients, in particular.

The aim of this study was to evaluate the success rates of implants placed in alveolar sockets immediately after the extraction of teeth or with a standard approach in normal alveolar bone in periodontally compromised patients.
KILINÇ, GÜNDOĞDU, AYDIN, BAŞ, ERTAŞ, DAYI

\section{MATERIALS AND METHODS}

A retrospective cohort study of a total of 12 periodontally compromised patients was done after a detailed examination of information and files of patients who were treated with dental implants at the Department of Oral and Maxillofacial Surgery and the Department of Prosthodontics, Faculty of Dentistry, University of Ataturk between January 2013 and January 2015.

In this study, patients who had implant placement both into healed bone after previous extraction and into the alveolar sockets in the same surgical session after extraction of periodontally hopeless teeth that had inadequate attachment and bone loss who could not be treated were selected for inclusion. Patients had been diagnosed with periodontitis based on a clinical and radiographic assessment (panoramic radiograph and computed tomography scan). Patients were excluded if they had any complicating systemic condition that contraindicated implant treatment, such as pregnancy, uncontrolled diabetes, and/or smoking.

All surgical operations were conducted under local anesthesia by single experienced surgeon. A fullthickness mucosal flap was elevated and the teeth were extracted gently. Debridement of granulation or any fibrous tissue that was present in the extraction sites was performed carefully and implants of appropriate dimensions were placed via standard protocols in the bone beyond the root apex and in the extraction sites, providing primer stability. Filling gaps between the implant and the extraction socket walls was done with a mixture of autogenous bone and collagenated equine particulate bone graft (OsteoBiol GenOs, Tecnoss Dental, Turin, Italy) When there was an insufficient vertical residual bone height in the posterior maxilla, sinus augmentation techniques were used for increasing bone height and dental implants were placed. The wound region was closed primarily with sutures by shifting the mucoperiosteal flap. All patients were instructed to take oral antibiotics (amoxicillin and clavulanic acid), anti-inflammatory medications (flurbiprofen), and mouth rinses (chlorhexidine gluconate) for 1 week. Sutures were removed after 1 week. The second-stage surgical procedure was performed following a healing period of about of 3 months. An interval of at least 2 weeks was 
Atatürk Üniv. Diş Hek. Fak. Derg.

J Dent Fac Atatürk Uni

Cilt:28, Sayı:2, Yıl: 2018, Sayfa, 216-221
KILINÇ, GÜNDOĞDU, AYDIN, BAŞ, ERTAŞ, DAYI allowed for prosthetic rehabilitation. All patients were rehabilitated with a definitive full or partial implantsupported porcelain-fused-to-metal prosthesis. Patients were followed up as clinical and radiological (panoramic radiograph) at 6-month intervals for 24 months, then at 1 year. Figures 1 through 3 present a case report of a patient treated with immediate implants and implant-supported full arch mandibular and maxillary porcelain-fused-to-metal prosthesis.

Implants were defined as successful or as having failed based on the following criteria described by Buser et al. ${ }^{23}$ : absence of persistent subjective complaints such as pain, foreign body sensation, and/or dysesthesia, absence of a peri-implant infection with suppuration, absence of mobility, or absence of a continuous radiolucency around the implant.

This study was approved by the regional ethics committee.

\section{Data Analysis}

The statistical analyses were performed using SPSS Version 20 Software (SPSS Inc., Chicago, IL, USA). For the estimation of implants' survival, a Kaplan-Meier analysis was used.

\section{RESULTS}

Twelve patients (four female and eight male) ranging in age from 27 to 62 years (mean 48.6 years) were studied; the mean duration of follow-up was 27 months (range 18-36 months). Patient and study variables are shown in Table 1.
Table 1. Patient and Study Variables

\begin{tabular}{ll}
\hline Number of patients & 12 \\
Male & 8 \\
Female & 4 \\
$\begin{array}{l}\text { Mean of age of patients, mean (range) } \\
\text { Duration of follow-up, months, mean }\end{array}$ & $48.6(27-62)$ \\
(range) & \\
Number of fixed full arch prosthesis & 18 \\
Number of fixed partial arch prosthesis & 10 \\
\hline
\end{tabular}

A total of 152 implants (85 Implance, 67 Implant Direct) were placed (89 in the maxilla, 63 in the mandible). Of these, 83 (54.6\%) were placed immediately into alveolar sockets following extraction and 69 (45.4\%) into normal alveolar bone (Table 2).

Only 3 of the 152 implants failed (Table 2). All of the implant failures occurred at the second-stage surgery. Two implant were lost in the maxilla and 1 was lost in the mandible. Two of three failed implants were placed immediately, and the other was placed with a standard approach (non-immediate) with a sinus lift augmentation procedure. After removal of the failed implants in the maxilla, these sites were left to heal by an appropriately performed debridement and the prosthetic plan was changed. However, in the mandible, the failed implant placed in tooth number 32 was removed and after debridement was performed, a new implant was placed in this area. Autogenous grafts obtained from the mandibular symphysis were applied to this region and primer stabilization was achieved. There was no failure at 12 months' follow-up.

The success rate for all immediately placed implants was $97.6 \%$, and the success rate for all implants placed as non-immediate was $98.6 \%$.(Table 2 )

Table 2. Survival rates and distribution of implants placed in the maxilla and mandible

\begin{tabular}{|c|c|c|c|c|c|c|c|c|c|c|}
\hline & Central & Lateral & Canine & $\begin{array}{c}\text { First } \\
\text { premolar }\end{array}$ & $\begin{array}{l}\text { Second } \\
\text { premolar }\end{array}$ & $\begin{array}{l}\text { First } \\
\text { molar }\end{array}$ & $\begin{array}{c}\text { Second } \\
\text { molar }\end{array}$ & Total & Failed & $\begin{array}{c}\text { SR } \\
(\%) \\
\end{array}$ \\
\hline Maxilla & 17 & 6 & 15 & 13 & 17 & 10 & 11 & 89 & 2 & 97.8 \\
\hline Immediate & 12 & 3 & 15 & 5 & 10 & 4 & 2 & 51 & 1 & 98 \\
\hline $\begin{array}{l}\text { Non- } \\
\text { immediate }\end{array}$ & 5 & 3 & - & 8 & 7 & 6 & 9 & 38 & 1 & 97.3 \\
\hline Mandible & 3 & 7 & 10 & 12 & 8 & 11 & 12 & 63 & 1 & 98.4 \\
\hline Immediate & 3 & 6 & 9 & 8 & 3 & 1 & 2 & 32 & 1 & 96.9 \\
\hline $\begin{array}{l}\text { Non- } \\
\text { immediate }\end{array}$ & - & 1 & 1 & 4 & 5 & 10 & 10 & 31 & - & 100 \\
\hline Immediate & 15 & 9 & 24 & 13 & 13 & 5 & 4 & 83 & 2 & 97.6 \\
\hline $\begin{array}{l}\text { Non- } \\
\text { immediate }\end{array}$ & 5 & 4 & 1 & 12 & 12 & 16 & 19 & 69 & 1 & 98.6 \\
\hline Total & 20 & 13 & 25 & 25 & 25 & 21 & 23 & 152 & 3 & 98 \\
\hline
\end{tabular}

- SR: Survival rate. 
Atatürk Üniv. Diş Hek. Fak. Derg.

J Dent Fac Atatürk Uni

Cilt:28, Sayı:2, Yıl: 2018, Sayfa, 216-221
KILINÇ, GÜNDOĞDU, AYDIN, BAŞ, ERTAŞ, DAYI
The success rate of implants placed in the maxilla was $98 \%$ for the immediate implantation and $97.3 \%$ for the conventional implantation. The success rate of implants placed in the mandible was $96.9 \%$ for the immediate implantation and $100 \%$ for the standard implantation. (Table 2)

\section{DISCUSSION}

In periodontally compromised patients, multiple extractions may be needed according to indication, due to risking more bone loss if tooth extraction is not done. Standard protocols extend the duration of treatment and patients may have some difficulties accepting the treatment considering the 6-month waiting period for healing of the extraction site and an additional 3-to 6-month period of additional osseointegration. This may lead to a further increase in existing bone loss. Immediate implantation can be very attractive and suitable in this case. However, negative opinions about immediate implantation in this patient group may affect the attitudes of clinicians against this procedure and ultimately cause patients to be deprived of this procedure from which they can benefit. This study was intended to contribute to the topic of whether the success rate of immediate implantation would be comparable to that of nonimmediate implant placement in periodontally compromised patients.

The present study has demonstrated that survival rates of osseointegrated implants replaced in the alveolar socket of teeth extracted due to periodontitis are similar to survival rates of implants placed in mature bone; implants placed by both methods exhibited significant success rates. The results of this study are comparable to those reported in published studies concerning immediate implant placement in periodontally compromised patients; some studies reported lower survival rates than this study. In a study with similar average follow-up times to the present study, Evian et al. ${ }^{24}$ investigated the relationship between periodontal disease and immediate implant placement and found a $78.18 \%$ survival rate of the immediate implants. They reported that implant survival was compromised by a history of periodontitis but was not affected by immediate or delayed placement Horwitz et al. found a $65 \%$ survival rate after immediate implant placement in the periodontally compromised extraction sites group. ${ }^{25}$ On the other hand, the results are comparable to those reported in other studies focusing on the same issues. In a study with a design similar to that of the present study, Alves et al. ${ }^{21}$ reported the 3-year cumulative survival rate was $100 \%$. In patients with periodontitis who participated in a study that included a 1-year postoperative observation period, Rabel and Köhler ${ }^{26}$ found the survival rate to be $95.8 \%$ in the immediate implantation group. Crespi et al. reported that dental implants that were immediately placed in periodontally infected sockets (survival rate of 98.9\%) showed no significant differences compared to implants placed in uninfected sites. In addition, when we look at the different studies including patient groups with periodontitis with immediate implantation, it was seen that they handled all other infectious conditions (such as periapical, endodontic infections) together, rather than specifically examining periodontal infections. ${ }^{3,27,28}$ These studies reported high survival rates. Taking into account the findings of previous studies in combination with the findings of this study, we see that immediate implantation may be preferred in this patient group.

In the present study, placement of a new implant by providing primary stabilization and using autogenous grafts in the same site after removal of 1 of the failed implants (number 32) and no failure during the 12-month follow-up period, it is important to respond positively to the implant re-treatment, which presents a challenging therapeutic process to the clinician. In this case, the same size $(3.7 \mathrm{~mm}, 13$ $\mathrm{mm}$ ) implant was successfully placed in the number 42 tooth. Therefore, we do not have a clear idea about the reason for the failure of the implant. Another failed implant was placed in the fresh extraction socket of the maxillary first molar tooth. The amount of residual bone between the maxillary sinus floor and root apex was inadequate, but the interradicular alveolar bone seemed to be suitable for implant placement, and the implant was placed in this area with primer stabilization and the gap around the implant filled with a xenograft. When we examined the cause of failure, the presence of a sufficient amount of bone beyond the root apex, which is an important factor in immediate implantation, was dramatic. Even in the case of providing primer stabilization within the alveolar socket, it has come to our attention that it is extremely important to have a significant amount of residual bone beyond the furcation or root apexes for support of implant stabilization through this region. For this reason, we recommend considering the

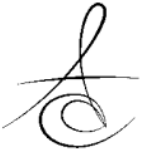


Atatürk Üniv. Diş Hek. Fak. Derg.

J Dent Fac Atatürk Uni

Cilt:28, Sayı:2, Yıl: 2018, Sayfa, 216-221

amount of residual bone beyond the apex together with the current bone structure of the maxillary while installing an implant to the maxillary molar teeth and to take additional measures (such as a sinus floor lift) accordingly.29 We think that the failure of this case is due to the technical strategy rather than periodontitis. The last of the failed implants were placed by the conventional method using the lateral window sinus augmentation procedure. A study by Zinser et al. ${ }^{30}$ performed on 224 patients (1045 implants) showed an average survival rate of $93.3 \%$ and analyzed the predictors of implant failure following maxillary sinus augmentation. The study reported factors that may affect implant failure: the ASA status, smoking, residual crestal bone height, the age of the patient, the choice of graft materials and surgical techniques, and no adjacent teeth or implants. In this case, the fact that the residual bone height $(5 \mathrm{~mm})$ was relatively inadequate and there were no adjacent teeth may have affected the failure of the implant.

Limitations of the present study include its moderate sample size and the absence of detailed radiographic and periodontal measurements. Notwith standing these limitations, our findings show that both immediate implant placement and standard nonimmediate implant placement in periodontally compromised patients receiving treatment of implantsupported fixed full or partial prostheses are safe and preferable treatment modalities. However, a more rigorous patient selection and treatment plan in this patient group and a tight protocol to eliminate infected tissues from the alveolar socket will help to increase the success of immediate implantation. Further studies should include a longer follow-up time, a larger number of patients, and a more detailed clinical and radiographic analysis.

Conflict of interest. The authors declare that they have no competing interests

Funding. This research had no source of funding

Ethical approval. This study was reviewed and approved by the regional ethics committee, Ataturk University, Faculty of Dentistry Local Ethics Committee

Adnan Kılınç ORCID ID: 0000-0003-4520-1271 Mustafa Gündoğdu ORCID ID:0000-0003-2527-0392 Tuğba Aydın ORCID ID:0000-0002-9675-5509 Mehmet Zahit Baş ORCID ID:0000-0003-0892-4067 Ertunç Dayı ORCID ID: 0000-0001-7201-2025
KILINÇ, GÜNDOĞDU, AYDIN, BAŞ, ERTAŞ, DAYI

\section{REFERENCES}

1. Branemark PI, Hansson BO, Adell R, Breine $U$, Lindstrom J, Hallen O, Ohman A: Osseointegrated implants in the treatment of the edentulous jaw. Experience from a 10-year period. Scand J Plast Reconstr Surg Suppl 1977; 16:1-132.

2. Chrcanovic BR, Martins MD, Wennerberg A: Immediate placement of implants into infected sites: a systematic review. Clin Implant Dent Relat Res 2015; 17 Suppl 1:e1-e16.

3. Casap N, Zeltser C, Wexler A, Tarazi E, Zeltser R: Immediate placement of dental implants into debrided infected dentoalveolar sockets. J Oral Maxillofac Surg 2007; 65:384-92.

4. Paolantonio M, Dolci M, Scarano A, d'Archivio D, di Placido G, Tumini $V$, Piattelli A: Immediate implantation in fresh extraction sockets. A controlled clinical and histological study in man. J Periodontol 2001; 72:1560-71.

5. Schropp L, Kostopoulos L, Wenzel A: Bone healing following immediate versus delayed placement of titanium implants into extraction sockets: a prospective clinical study. Int J Oral Maxillofac Implants 2003; 18:189-99.

6. Lee CT, Chiu TS, Chuang SK, Tarnow D, Stoupel J: Alterations of the bone dimension following immediate implant placement into extraction socket: systematic review and meta-analysis. J Clin Periodontol 2014; 41:914-26.

7. Lang NP, Pjetursson BE, Tan K, Bragger U, Egger M, Zwahlen M: A systematic review of the survival and complication rates of fixed partial dentures (FPDs) after an observation period of at least 5 years. II. Combined tooth--implant-supported FPDs. Clin Oral Implants Res 2004; 15:643-53.

8. Pjetursson BE, Tan K, Lang NP, Bragger U, Egger M, Zwahlen M: A systematic review of the survival and complication rates of fixed partial dentures (FPDs) after an observation period of at least 5 years. Clin Oral Implants Res 2004; 15:667-76.

9. Altintas NY, Taskesen F, Bagis B, Baltacioglu $E$, Cezairli B, Senel FC: Immediate implant placement in fresh sockets versus implant placement in healed bone for full-arch fixed prostheses with conventional loading. Int J Oral Maxillofac Surg 2016; 45:226-31.

10. Schwartz-Arad D, Laviv A, Levin L: Survival of immediately provisionalized dental implants placed immediately into fresh extraction sockets. J

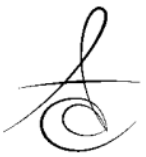


Atatürk Üniv. Diş Hek. Fak. Derg.

J Dent Fac Atatürk Uni

Cilt:28, Sayı:2, Yıl: 2018, Sayfa, 216-221
KILINÇ, GÜNDOĞDU, AYDIN, BAŞ, ERTAŞ, DAYI
Periodontol 2007; 78:219-23.

11. Karoussis IK, Salvi GE, Heitz-Mayfield L, Bragger U, Hammerle $\mathrm{CH}$, Lang NP: Long-term implant prognosis in patients with and without a history of chronic periodontitis: a 10-year prospective cohort study of the ITI Dental Implant System. Clin Oral Implants Res 2003; 14:329-39.

12. Matarasso S, Rasperini G, Iorio Siciliano V, Salvi GE, Lang NP, Aglietta M: A 10-year retrospective analysis of radiographic bone-level changes of implants supporting single-unit crowns in periodontally compromised vs. periodontally healthy patients. Clin Oral Implants Res 2010; 21:898-903.

13. Mengel R, Schroder T, Flores-de-Jacoby $L$ : Osseointegrated implants in patients treated for generalized chronic periodontitis and generalized aggressive periodontitis: 3 - and 5-year results of a prospective long-term study. J Periodontol 2001; 72:977-89.

14. Leonhardt A, Grondahl K, Bergstrom C, Lekholm U: Long-term follow-up of osseointegrated titanium implants using clinical, radiographic and microbiological parameters. Clin Oral Implants Res 2002; 13:127-32.

15. Klokkevold PR, Han TJ: How do smoking, diabetes, and periodontitis affect outcomes of implant treatment? Int J Oral Maxillofac Implants 2007; 22 Suppl:173-202.

16. Jiang BQ, Lan J, Huang HY, Liang J, Ma XN, Huo LD, $\mathrm{Xu} X$ : A clinical study on the effectiveness of implant supported dental restoration in patients with chronic periodontal diseases. Int J Oral Maxillofac Surg 2013; 42:256-9.

17. Barzilay I: Immediate implants: their current status. Int J Prosthodont 1993, 6:169-75.

18. Becker W, Becker BE: Guided tissue regeneration for implants placed into extraction sockets and for implant dehiscences: surgical techniques and case report. Int J Periodontics Restorative Dent 1990; 10:376-91.

19. Werbitt MJ, Goldberg PV: The immediate implant: bone preservation and bone regeneration. Int J Periodontics Restorative Dent 1992; 12:206-17.

20. Wagenberg B, Froum SJ: A retrospective study of 1925 consecutively placed immediate implants from 1988 to 2004. Int J Oral Maxillofac Implants 2006; 21:71-80.

21. Alves CC, Correia AR, Neves M: Immediate implants and immediate loading in periodontally compromised patients-a 3-year prospective clinical study. Int ] Periodontics Restorative Dent 2010; 30:447-55.

22. Villa R, Rangert B: Early loading of interforaminal implants immediately installed after extraction of teeth presenting endodontic and periodontal lesions. Clin Implant Dent Relat Res 2005; 7 Suppl 1:S28-35.

23. Buser D, Janner SF, Wittneben JG, Bragger $U$, Ramseier CA, Salvi GE: 10-year survival and success rates of 511 titanium implants with a sandblasted and acid-etched surface: a retrospective study in 303 partially edentulous patients. Clin Implant Dent Relat Res 2012; 14:839-51.

24. Evian CI, Emling R, Rosenberg ES, Waasdorp JA, Halpern W, Shah S, Garcia M: Retrospective analysis of implant survival and the influence of periodontal disease and immediate placement on long-term results.Int J Oral Maxillofac Implants 2004;19:393-8.

25. Horwitz J, Zuabi O, Peled M, Machtei EE: Immediate and delayed restoration of dental implants in periodontally susceptible patients: 1-year results. Int J Oral Maxillofac Implants 2007; 22:423-9.

26. Rabel A, Kohler SG: [Microbiological study on the prognosis of immediate implant and periodontal disease]. Mund Kiefer Gesichtschir 2006; 10:7-13.

27. Meltzer AM: Immediate implant placement and restoration in infected sites. Int J Periodontics Restorative Dent 2012; 32:e169-73.

28. Villa $R$, Rangert B: Immediate and early function of implants placed in extraction sockets of maxillary infected teeth: a pilot study. J Prosthet Dent 2007; 97:96-108.

29. Bruschi GB, Crespi R, Cappare P, Bravi F, Bruschi E, Gherlone E: Localized management of sinus floor technique for implant placement in fresh molar sockets. Clin Implant Dent Relat Res 2013; 15:24350.

30. Zinser MJ, Randelzhofer $P$, Kuiper $L$, Zoller JE, De Lange GL: The predictors of implant failure after maxillary sinus floor augmentation and reconstruction: a retrospective study of 1045 consecutive implants. Oral Surg Oral Med Oral Pathol Oral Radiol 2013; 115:571-82

\section{Yazışma Adresi}

Dr. Öğr. Üyesi Adnan KILINÇ Department of Oral and Maxillofacial Surgery, Faculty of Dentistry, Ataturk University, Erzurum, Turkey 25240, Tel.: 0904422311734 , Fax: 09044223609 45, e-mail: adnankilin@yahoo.com) 